\title{
The comparison of the operating parameters in an aircraft radial piston engine fuelled by 100LL and ES95 gasoline
}

\begin{abstract}
Small aviation develops very dynamically. This is a result of airplane general availability and their lower prices. At the same time, however, the maintenance costs of airplanes increases. It particularly concerns the operation cost where fuel is its substantial part. At the moment special 100L L gasoline is used to fuel aircraft piston engines. It is about 20\% more expensive than ES95 gasoline of comparable properties.

The paper shows the results of test-bed research conducted on the radial piston aircraft engine fuelled by aircraft 100LL gasoline and automotive ES95 gasoline. The object of research was ASz-62IR engine by WSK Kalisz fitted with an experimental fuel injection system. The power, fuel consumption and cylinder head temperatures were analysed in the selected typical operating points. The testing was carried out in a steady state. It was proven that it is possible to exchange (replace) fuels with no engine power loss with a miniscule increase of fuel consumption.
\end{abstract}

Key words: internal combustion engine, radial engine, fuel injection, 100LL gasoline, ES95 gasoline, test-bed research

\section{Porównanie parametrów użytkowych gwiazdowego tlokowego silnika lotniczego zasilanego benzyną lotniczą 100LL i benzyną samochodową ES95}

\begin{abstract}
Lotnictwo matych samolotów rozwija się bardzo dynamicznie. Wynika to z coraz większej dostępności samolotów oraz coraz nizssych ich cen; jednak koszty utrzymania samolotu sa nadal bardzo wysokie. Dotyczy to przede wszystkim samolotów, w których koszty paliwa stanowiq znacząca część kosztów eksploatacyjnych. Obecnie lotnicze silniki ttokowe zasilane sa specjalnym paliwem - benzyna lotnicza typu 100LL, której koszt jest o 20\% wyższy niż porównywalnej wtaściwościami benzyny samochodowej ES95.

W artykule przedstawiono wyniki badań stanowiskowych gwiazdowego, tlokowego silnika lotniczego zasilanego dwoma paliwami: benzyna lotnicza 100LL oraz benzyna samochodowa ES95. Obiektem badań byt silnik ASz-62IR produkowany przez WSK „PZL-Kalisz” S.A., wyposażony w eksperymentalny uktad wtrysku paliwa do rur dolotowych. Analizie poddano moc, zużycie paliwa oraz temperature głowic $w$ wybranych, charakterystycznych punktach pracy. Badania przeprowadzono w stanach ustalonych. Wykazano, że możliwa jest zamiana paliwa bez utraty mocy silnika, jedynie przy niewielkim wzroście jego zużycia.
\end{abstract}

Słowa kluczowe: silnik spalinowy, silnik gwiazdowy, wtrysk paliwa, benzyna 100LL, benzyna ES95, badania stanowiskowe

\section{Introduction}

Small aviation develops very dynamically both in Europe and worldwide. The development concerns recreation planes, taxi-planes, farming planes, small cargo planes. Most of them are powered with piston engines because of a low price of such engines as well as their cheap maintenance as compared with turbine engines.

The cost of fuel is a considerable part of the maintenance expenses of internal combustion engines. At present aviation piston engines are fuelled by special fuel - aviation 100LL gasoline that is about $20 \%$ more expensive than automotive ES95 gasoline of comparable properties. 100LL is the only one currently produced that contains lead $[1,2]$. The planned ecological restrictions in aviation within the next few years kindle much interest in alternative fuels $[1,2,3$, 4]. Nowadays, they are looking for fuel to substitute 100LL gasoline that is being phased out from production because of lead compounds.

\section{Wprowadzenie}

Lotnictwo małych samolotów rozwija się bardzo dynamicznie zarówno w Europie, jak i na całym świecie. Rozwój ten obejmuje samoloty przeznaczone do rekreacji, taksówki powietrzne, samoloty rolnicze oraz małe samoloty transportowe. Są to przeważnie samoloty napędzane silnikami tłokowymi, co wynika ze stosowanych mocy silników, z niskich kosztów zarówno zakupu silnika, jak również jego eksploatacji - w porównaniu z silnikami turbinowymi.

Koszty paliwa stanowią znaczącą część kosztów eksploatacyjnych silników spalinowych. Obecnie lotnicze silniki tłokowe zasilane są specjalnym paliwem - benzyną lotniczą typu 100LL, której koszt jest o 20\% wyższy niż porównywalnej właściwościami benzyny samochodowej ES95. Jest to jedyne obecnie produkowane paliwo zawierające związki ołowiu [1,2]. Planowane w najbliższych latach obostrzenia ekologiczne stawiane przed lotnictwem powodują znaczący 
Fuels containing ethanol are frequently used as alternative ones. According to experimental tests, alcohol based fuel can be used only if its dosage is from $10 \%$ to $19 \%$ [2] larger than that of gasoline depending on a gasoline composition and engine adjustment. Simultaneously, if such an ethanol based fuel is used, it is necessary to use some additional protection for fuel system elements $[4,5]$.

The simplest solution seems to use a commonly available fuel, i.e. automotive ES95 gasoline. The fuel is similar to the aviation one with regard to its calorific value, physical properties (density, viscosity) and storage properties [6, 7 , $8,9,10]$.

Table 1 gives some basic physical and chemical properties of the aviation and automotive gasoline. It can be noted that the properties of both fuels are almost identical. The octane number, explosiveness limits and calorific value are very similar. However, there are differences in the hydrocarbon fraction in the composition of both fuels. It changes the boiling point range and, most importantly, the vapour pressure. This fact will influence the processes of mixture formation and possibly combustion. Thus, it seems possible to use this fuel in contemporary fuel systems with no necessity of any modifications of design or material. Any possible changes may only concern the adjustment of the fuelling and ignition systems.

To that end the authors carried out the preliminary research in order to verify the possibility of the automotive gasoline to be used for fuelling aviation engines as well as the impact of this exchange on the engine operating parameters. The spotted differences between these fuels will also be applied to determine any necessary changes to adjust the fuel control system.

\section{The object and scope of research}

\subsection{The object}

The research was carried out at the engine test bench at WSK ,PZL-Kalisz" on ASz-62IR engine fitted with an electronic injection system designed for the project conducted by the scientists from Lublin University of Technology.

The tested unit is an aircooled four-stroke gasoline engine of 9 cylinders in a radial configuration, supercharged by a radial compressor powered by the engine crankshaft. The total engine cubic capacity is $29.87 \mathrm{dm}^{3}$, and the compression ratio is $6.4: 1$. The maximum take-off power is $1000 \mathrm{HP}$ at $2200 \mathrm{rpm}$. The maximum fuel consumption is $280 \mathrm{~kg} / \mathrm{h}$. The engine is fuelled with Avgas 100LL and ES95 through an electronic injection system. wzrost zainteresowania paliwami alternatywnymi [1-4]. Poszukiwane jest obecnie zastępcze paliwo dla benzyny 100LL wycofywanej z produkcji.

Jako paliwa alternatywne najczęściej wykorzystywane są paliwa oparte na alkoholu etylowym. Z badań doświadczalnych wynika, że zastosowanie paliwa alkoholowego wymaga zwiększenia jego dawkowania w stosunku do benzyny od 10 do 19\% [2], w zależności od składu paliwa oraz regulacji silnika. Jednocześnie zastosowanie paliwa zawierającego etanol powoduje konieczność zastosowania dodatkowej ochrony elementów układu paliwowego $[4,5]$.

Najprostszym rozwiązaniem wydaje się zastosowanie powszechnie dostępnego paliwa - benzyny stosowanej do samochodów ES95. Paliwo to jest podobne do benzyny lotniczej pod względem energetycznym, właściwości fizycznych (gęstość, lepkość) oraz właściwości związanych z przechowywaniem [6-10].

W tabeli 1 przedstawiono podstawowe właściwości fizykochemiczne benzyny lotniczej i samochodowej. Można zauważyć, że właściwości obu benzyn są podobne. Zarówno liczba oktanowa, granice wybuchowości, jak i wartość opałowa są bardzo zbliżone. Istnieją jednakże różnice wynikające z różnicy frakcji węglowodorów występujących w składach obu paliw. Powoduje to zmianę w zakresie temperatur wrzenia, a przede wszystkim prężności par. Będzie to wpływać na proces tworzenia mieszanki i być może na proces spalania.

$\mathrm{Z}$ analizy porównawczej benzyn wynika, że możliwe jest bezpośrednie zastosowanie tego paliwa do istniejących układów paliwowych, bez konieczności wprowadzania modyfikacji konstrukcyjnych i materiałowych; jedynie

Table 1. The physical and chemical properties of aviation and automotive gasoline [6-9]

Tabela 1. Właściwości fizykochemiczne benzyny lotniczej i samochodowej [6-10]

\begin{tabular}{|c|c|c|}
\hline Properties/właściwości & $\begin{array}{l}\text { 100LL aviation gasoline/ } \\
\text { benzyna lotnicza }\end{array}$ & $\begin{array}{c}\text { ES95 automotive gasoline/ } \\
\text { benzyna samochodowa }\end{array}$ \\
\hline $\begin{array}{l}\text { Chemical composition/sktad chemiczny: } \\
\text { - simple hydrocarbons/węglowodory proste } \\
\text { - aromatic compounds/zwiazki aromatyczne } \\
\text { - lead compounds/zwiąki ołowiu }\end{array}$ & $\begin{array}{c}69.4 \% \\
30 \% \\
0.6 \%\end{array}$ & $\begin{array}{c}65 \% \\
35 \% \\
0\end{array}$ \\
\hline Density/gęstość $\left[\mathrm{kg} / \mathrm{m}^{3}\right]$ & $700-80$ & $725-780$ \\
\hline Boiling point/temperatura wrzenia & $30-170^{\circ} \mathrm{C}$ & $30-215^{\circ} \mathrm{C}$ \\
\hline Vapour pressure in/prężność par w $20^{\circ} \mathrm{C}[\mathrm{kPa}]$ & $38-48$ & $60-80$ \\
\hline Octane number/liczba oktanowa & 100 & 95 \\
\hline Calorific value/wartość opałowa $[\mathrm{MJ} / \mathrm{kg}]$ & 43.5 & 43 \\
\hline $\begin{array}{l}\text { Explosiveness limits/granice wybuchowości }[\% \mathrm{v} / \mathrm{v}] \text { : } \\
\text { - lower/dolna } \\
\text { - upper/górna }\end{array}$ & $\begin{array}{c}1.4 \\
11.5\end{array}$ & $\begin{array}{c}1.1 \\
10.6\end{array}$ \\
\hline Self-ignition point/temperatura samozapłonu & $360^{\circ} \mathrm{C}$ & $340^{\circ} \mathrm{C}$ \\
\hline
\end{tabular}

mogą być konieczne zmiany w sterowaniu tworzeniem mieszanki i zapłonu. Dlatego też autorzy przeprowadzili badania wstępne, mające na celu określenie możliwości zastosowania benzyny samochodowej do zasilania silnika lotniczego oraz wpływu tej zmiany na parametry użytkowe silnika. Identyfikacja różnic miedzy paliwami wykorzystana będzie także do określenia koniecznych zmian nastaw układu sterowania paliwem. 


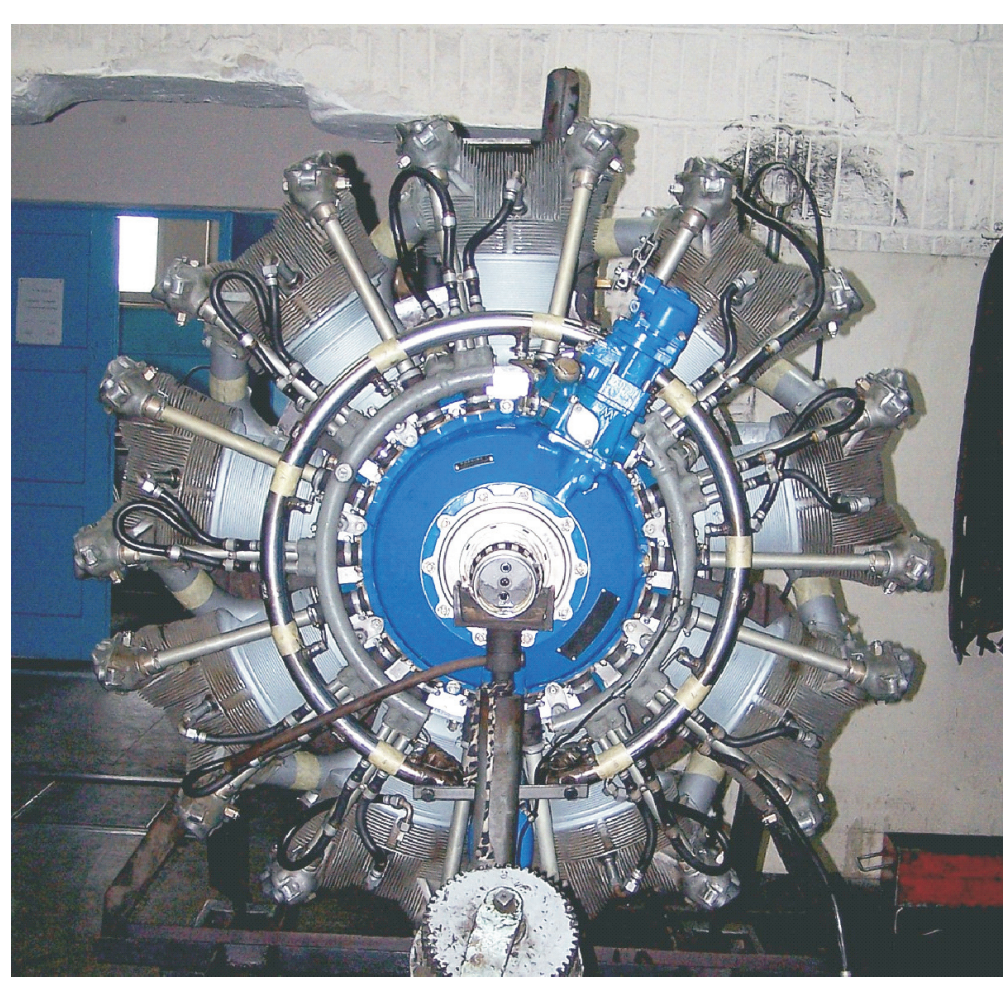

Fig. 1. Test stand. ASz-62IR Engine. Front view Rys. 1. Obiekt badań - silnik ASz-62IR - widok z przodu

\subsection{The measurement systems}

The basic equipment of the WSK Kalisz test stand was used for the testing. The following values were measured:

- engine torque - a reactionary moment measured by means of a balance system, the measurement accuracy $\pm 1 \mathrm{~N} \cdot \mathrm{m}$, subsequently converted into power corrected to NTP conditions

- fuel consumption - measured by volume, subsequently converted into mass, including a fuel temperature correction, the measurement accuracy $\pm 1 \mathrm{~kg} / \mathrm{h}$

- head temperature - measured by means of thermocouples as washers placed under the spark-plugs of the rear part of the engine head, the measurement accuracy $\pm 1^{\circ} \mathrm{C}$.

The engine operating conditions were defined as engine speed and pressure in the inlet individual runners and set according to the indications of the electronic injection system. Engine speed was measured according to the signal of a magnetically induced rotational position sensor co-operating with a phonic wheel. The measurement accuracy equals \pm 0.1 $\mathrm{rpm}$. The pressure in the inlet individual runners was measured by means of MPX 250 sensor featuring the measure range of $30-250 \mathrm{kPa}$ of absolute pressure and the measurement accuracy of $1 \%$.

The measurements were done manually because of low frequency of signals.

\subsection{The scope}

The tests covered the engine operation in a steady state at various engine speeds. The measurements were carried out for maintenance characteristic, i.e. for engine speed $n$ ranging from 1660 to $2200 \mathrm{rpm}$ (Fig. 2). The measurement points are normally used for testing of each new engine.

\section{Obiekt i zakres badań}

\subsection{Obiekt badań}

Badania przeprowadzono na hamowni silnikowej WSK „PZL-Kalisz” S.A. na silniku ASz-62IR wyposażonym w elektroniczny układ wtrysku paliwa opracowany w ramach projektu celowego prowadzonego przez zespół Politechniki Lubelskiej.

Obiektem badań jest lotniczy silnik spalinowy w układzie gwiazdowym (rys. 1). Jest to silnik 9-cylindrowy, czterosuwowy o zapłonie iskrowym, chłodzony powietrzem, doładowany mechanicznie przez promieniową sprężarkę. Objętość skokowa silnika wynosi $29,87 \mathrm{dm}^{3}$, a stopień sprężania - 6,4:1. Maksymalna moc (moc startowa) wynosi $1000 \mathrm{KM}$ przy prędkości obrotowej $2200 \mathrm{obr} / \mathrm{min}$. Maksymalne zużycie paliwa $-230 \mathrm{~kg} / \mathrm{h}$. Silnik zasilany jest paliwem Avgas 100LL oraz ES95 z wykorzystaniem elektronicznie sterowanego układu wtrysku paliwa.

\subsection{System pomiarowy}

Podczas badań wykorzystano podstawowe wyposażenie stanowiska badawczego hamowni silnikowej w WSK Kalisz. Mierzono następujące wielkości:

- moment obrotowy silnika - mierzony jako moment reakcyjny za pomocą układu szalkowego, dokładność pomiarowa $\pm 1 \mathrm{~N} \cdot \mathrm{m}$, przeliczany następnie na moc korygowaną do warunków normalnych

- zużycie paliwa - mierzone objętościowo, przeliczane na masowe z korekcją od temperatury paliwa, dokładność pomiaru $\pm 1 \mathrm{~kg} / \mathrm{h}$

- temperatury głowic - mierzone z użyciem termopar umieszczonych w postaci podkładek pod świecami zapłonowymi tylnej części głowicy silnika, dokładność odczytu $\pm 1^{\circ} \mathrm{C}$.

Warunki pracy silnika, wyznaczone jako prędkość obrotowa i ciśnienie w rurach dolotowych, ustalane były na podstawie wskazań układu sterowania wtryskiem paliwa. Pomiar prędkości obrotowej dokonywany był na podstawie sygnału czujnika magnetoindukcyjnego współpracującego z kołem fonicznym, dokładność pomiaru wynosiła $\pm 0,1 \mathrm{obr} / \mathrm{min}$. Pomiar ciśnienia w rurach dolotowych dokonywany był za pomocą czujnika MPX 250: zakres pomiarowy 30-250 kPa ciśnienia bezwzględnego, dokładność pomiarowa - 1\%.

Ze względu na wolnozmienność sygnałów, pomiarów dokonywano ręcznie.

\subsection{Zakres badań}

Badania przeprowadzono w warunkach ustalonych dla różnych prędkości obrotowych silnika. Zakres badań obejmował punkty pracy silnika przy prędkościach obrotowych od 1550 do $2200 \mathrm{obr} / \mathrm{min}$ (rys. 2) znajdujących się na charakterystyce użytkowej silnika. Punkty te są wykorzystywane przy testach każdego nowego silnika. Badania przeprowadzono przy temperaturze otoczenia równej $30^{\circ} \mathrm{C}$ i ciśnieniu atmosferycznym $1005 \mathrm{hPa}$. 
The tests were carried out at the engine test house where the temperature was maintained at the level of $30^{\circ} \mathrm{C}$. During the tests the atmospheric pressure was $1005 \mathrm{hPa}$.

The tests were conducted for the same operating points of the engine fuelled by 100LL aviation and ES95 automotive gasoline. The engine torque, power, fuel consumption and head temperature were measured for each operating point.

The injection dosage was set to obtain the same mixture composition for each tested point. The agreed fuel dosage enabled achieving excess air coefficient $\lambda=0.9$ (measured at the joint outlet manifold from the $3 \mathrm{rd}$ and 4 th cylinder by means of LSU4 linear lambda oxygen sensor).

For each engine operating point the measurements were carried out in constant time. The time equalled 4 minutes. It resulted from the method of conducting the tests, consisting in keeping the engine operating at a given point for a time needed for the fuel consumption measurements and it was also determined as the shortest possible time needed to conduct the measurements in a steady state, due to heavy operating conditions of the sensors (temperature, vibrations and air blasts).

\section{The results}

Figure 3 shows the comparison of the power obtained when fuelled by both types of gasoline in the selected operating points. As noted the both lines almost overlap.

Figure 4 presents the differences between the power obtained for 100LL and ES95. The aviation gasoline parameters were assumed to be the basic value for all the comparisons. In the case of ES95 there was a slight increase of power for all the tested operating points. It ranged from 3 to $5 \mathrm{KM}$, which corresponds from 0.3 to $0.8 \%$ of the values obtained in the given points. Thus, the power increase is inconsiderable.

Greater differences were noted for fuel consumption (Fig. 5 and 6). Figure 5 shows that the fuel consumption increase was noticeable if fuelled by ES95 gasoline. Such an increase can be significant as it is about $6 \%$ for all the operating points (Fig. 6). The fuel consumption increase is probably due to the differences in the chemical composition and viscosity of both tested fuels.

The temperature of the engine heads changed as well - see Fig. 7. In this case the application of the automotive gasoline decreased the average temperature of the heads by several degrees. This decrease is given in Fig. 8 . The temperature decreased most, i.e. over $2^{\circ} \mathrm{C}$ when the engine operated at cruising and maximum power (the engine speeds were respectively: 2030 and $2100 \mathrm{rpm}$ ). The slightest temperature decrease, i.e. less than $1^{\circ} \mathrm{C}$ was observed for the power of $30 \%$ (the engine speed equalled $1660 \mathrm{rpm}$ ) and the starting power (2200 rpm).

The decrease of the average value was not significant. The difference ranging from 1 to $2 \%$ was much lower than the temperature distribution on particular cylinders - Fig. 9. It was noted that the discrepancies between the cylinder range from $18^{\circ} \mathrm{C}$ at the speed of $1660 \mathrm{rpm}$ up to $40^{\circ} \mathrm{C}$ at the speed of $2200 \mathrm{rpm}$. The authors also observed that the distribution was actually identical for both types of fuel. In all the cases cylinder 8 or 9 had the lowest while cylinder 7 or 5 , had the highest temperature.
Badania przeprowadzono w tych samych punktach pracy silnika zarówno przy zasilaniu benzyną lotniczą 100LL, jak i benzyną samochodową ES95. W każdym z punków mierzono moment obrotowy, moc, zużycie paliwa oraz temperaturę głowic.

Dawkę wtrysku ustalano, tak aby w każdym z badanych punktów uzyskiwać ten sam skład mieszanki. Przyjęto dawkę paliwa pozwalającą na uzyskanie współczynnika nadmiaru powietrza $\lambda=0,9$ (mierzonego ze wspólnego kolektora wylotowego dla cylindrów 3 i 4 za pomocą szerokozakresowej sondy lambda LSU4).

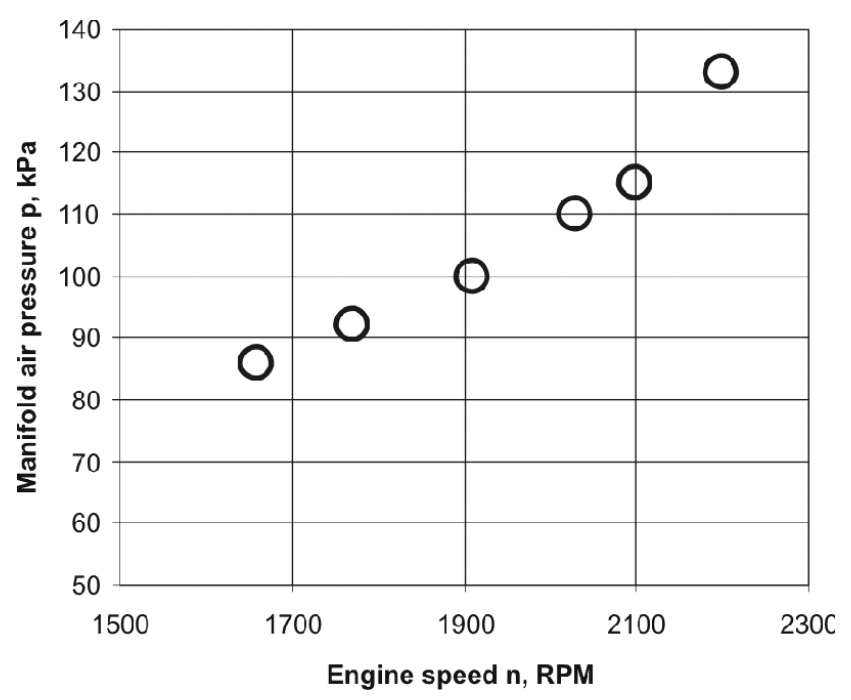

Fig. 2. Measurement points

Rys. 2. Punkty pomiarowe

W każdym punkcie pomiarowym silnik pracował około 4 minuty. Czas ten zapewniał ustabilizowanie pracy silnika, jego stanu termicznego oraz wykonanie wszystkich pomiarów.

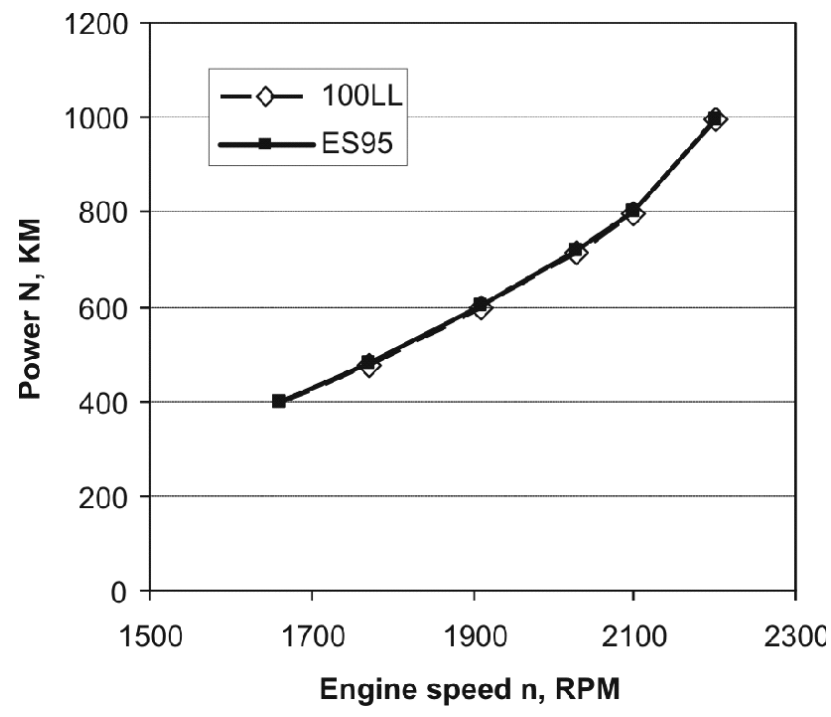

Fig. 3. The power obtained during the tests on 100LL and ES95 gasoline Rys. 3. Moc uzyskana podczas badań w paliwie 100LL I ES95 

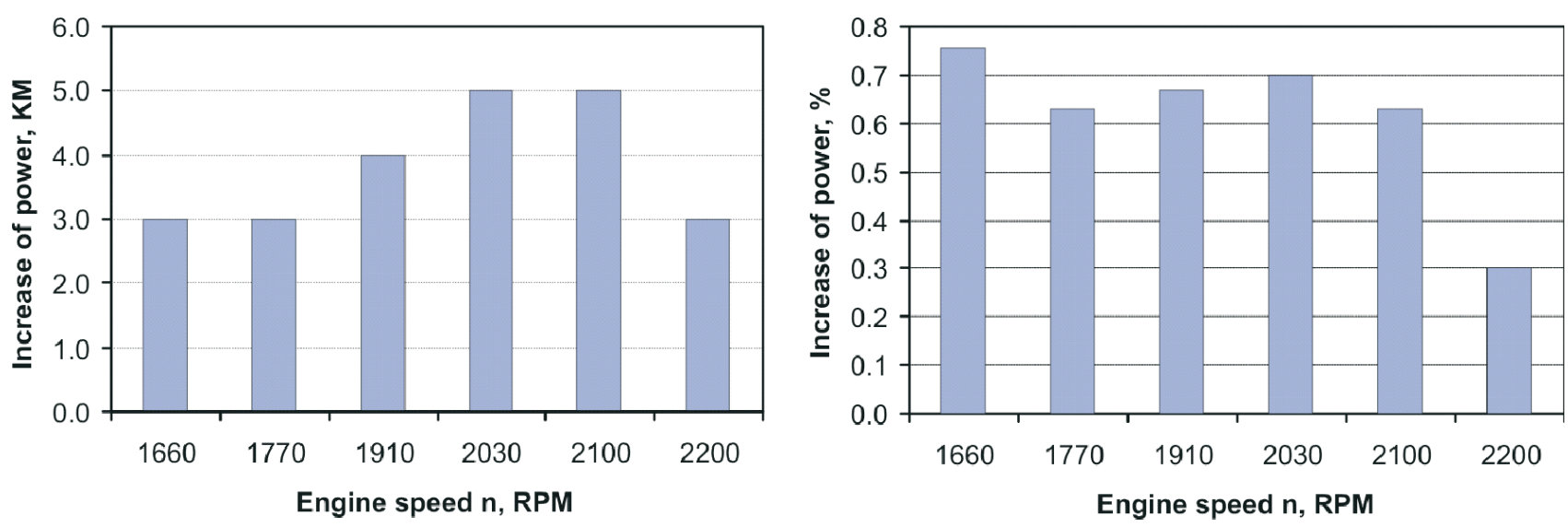

Fig. 4. Engine power change when ES95 substituted 100LL

Rys. 4. Zmiana mocy po zmianie zasilania silnika z paliwa 100LL na ES95

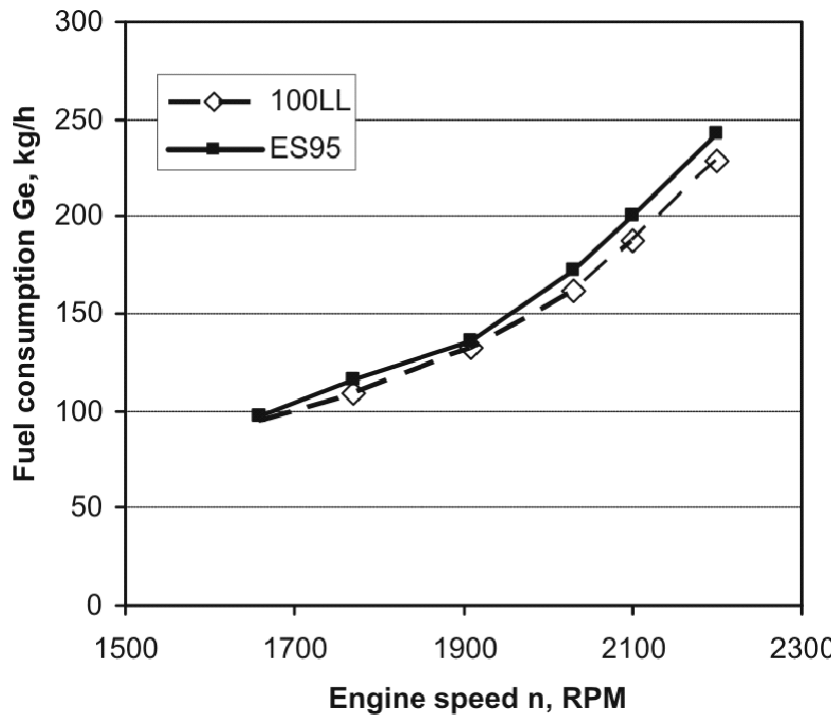

Fig. 5. Fuel consumption during the tests in the case of 100LL and ES95 gasoline

Rys. 5. Zużycie paliwa podczas badań z zastosowaniem paliwa $100 L L$ i ES95

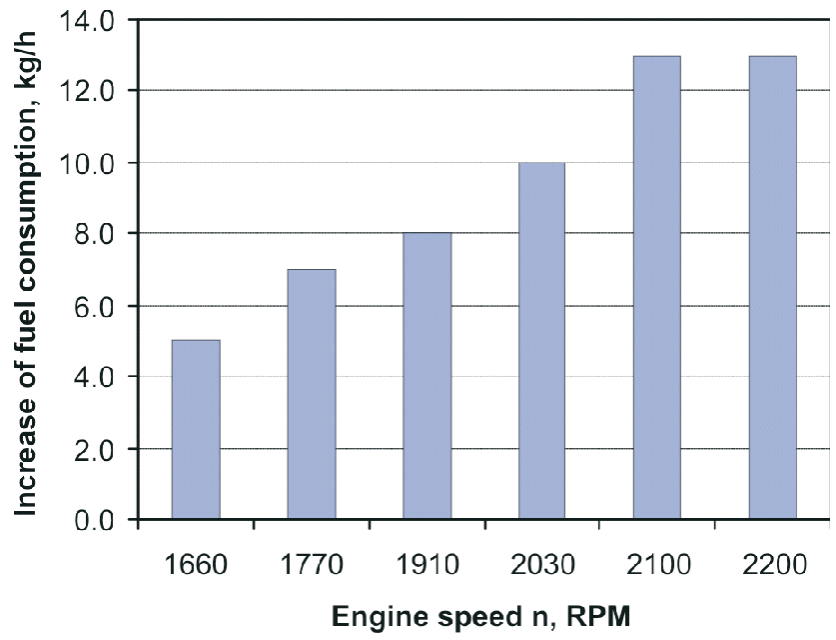

\section{Wyniki badań}

Na rysunku 3 przedstawiono porównanie uzyskanej mocy przy zasilaniu obydwoma paliwami w wybranych punktach pracy. Jak można zauważyć, obie linie prawie się pokrywają.

Na rysunku 4 przedstawiono natomiast różnice między mocami uzyskanymi przy użyciu benzyny lotniczej 100LL i samochodowej ES95. Jako wartość bazową do wszystkich porównań przyjęto benzynę lotniczą. We wszystkich badanych punktach widoczny jest niewielki wzrost mocy po zastosowaniu benzyny ES95. Waha się on od 3 do $5 \mathrm{KM}$, co odpowiada 0,3 do $0,8 \%$ wartości uzyskiwanych w danych punktach. Przyrost mocy jest zatem pomijalnie mały.

Większe różnice zaobserwowano w zużyciu paliwa (rys. 5 i 6). Na rysunku 5 wyraźnie widoczne jest zwiększenie godzinowego zużycia paliwa przy zasilaniu benzyną ES95. Wzrost ten można uznać już za istotny, gdyż we wszystkich punktach wynosi on około 6\% (rys. 6). Wzrost zużycia paliwa jest prawdopodobnie spowodowany różnicą w składach chemicznych oraz gęstości badanych paliw.

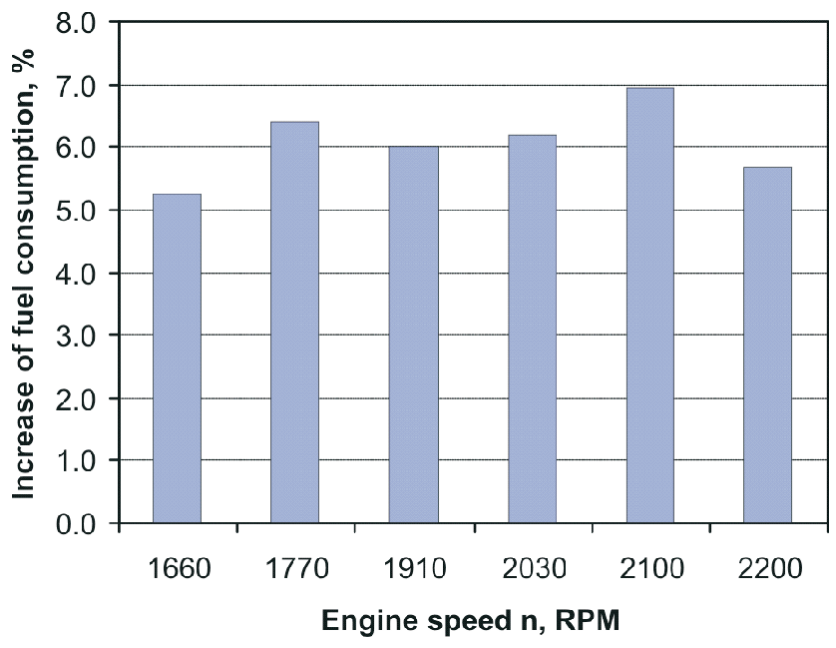

Fig. 6. Fuel consumption change when ES95 substituted 100LL

Rys. 6. Zmiana zużycia paliwa po zmianie zasilania silnika z paliwa 100LL na ES95 
The temperature distribution in the remaining cylinders was also similar in the selected measurement points. Thus, it can be supposed that the way particular cylinders are assembled (the leak-tightness of the piston-ring-cylinder assembly-PRC and the valve seats, the capacity of engine oil passages) is more important than the fuel type.

\section{Summary}

The analysis of the obtained results leads to the following conclusions:

1. Automotive ES95 gasoline seems to be a good replacement for the 100LL aviation fuel.

2. Such a substitution will not affect the engine power significantly. The observed increase in the engine power amounted to approximately $0.5 \%$ only.

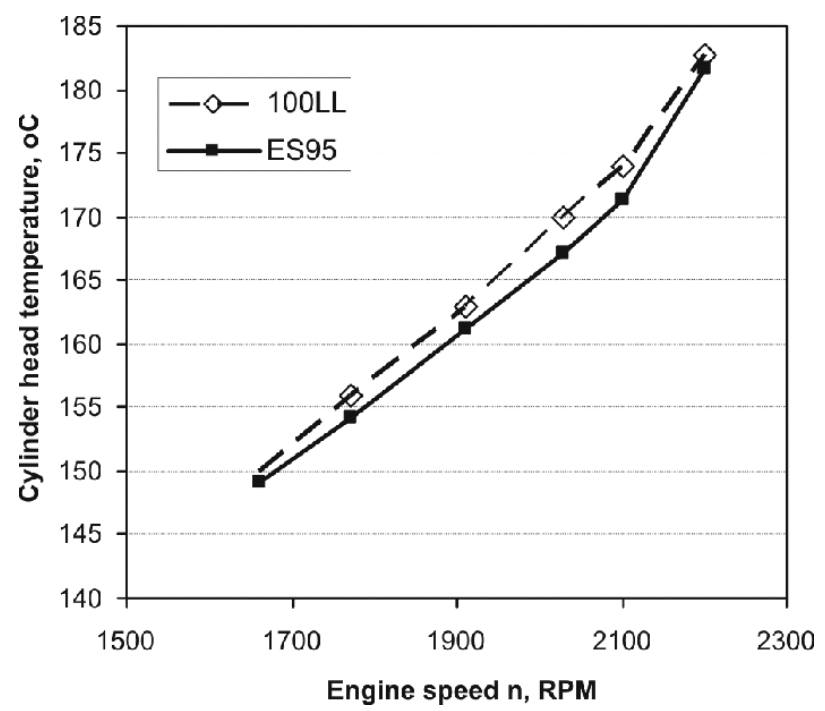

Fig. 7. Cylinder head average temperature during the tests for 100LL and ES95

Rys. 7. Średnia temperatura glowic w czasie badań przy użyciu paliwa 100LL i ES95

Engine speed n, RPM

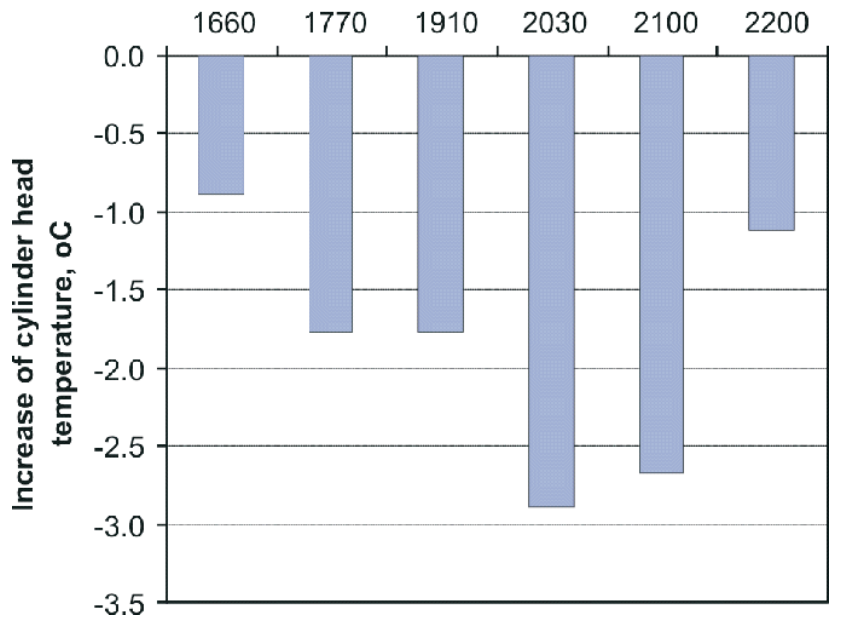

Zmianie uległy także temperatury głowic (rys. 7). W tym przypadku wprowadzenie benzyny samochodowej spowodowało spadek średniej temperatury głowic o kilka stopni (rys. 8). Największy spadek, wynoszący ponad $2^{\circ} \mathrm{C}$, występuje przy pracy silnika na mocy przelotowej i mocy maksymalnej (prędkości obrotowe silnika odpowiednio: 2030 i 2100 obr/min). Najmniejszy natomiast, wynoszący poniżej $1^{\circ} \mathrm{C}$, na $30 \%$ mocy (prędkość obrotowa równa $1660 \mathrm{obr} / \mathrm{min}$ ) oraz na mocy startowej (2200 obr/min).

Obniżenie średniej temperatury głowic nie jest znaczące. Różnica wynosząca od 1 do $2 \%$ jest dużo mniejsza niż rozrzut temperatur na poszczególnych cylindrach (rys. 9). Można zauważyć, że rozbieżności między cylindrami wynoszą od $18^{\circ} \mathrm{C}$ przy prędkości $1660 \mathrm{obr} / \mathrm{min}$ do nawet $40^{\circ} \mathrm{C}$ dla prędkości $2200 \mathrm{obr} / \mathrm{min}$. Jednocześnie można zauważyć, że rozrzut ten jest prawie identyczny dla obu paliw. We wszystkich przypadkach najniższą temperaturę głowicy ma cylinder 8 lub 9, a najwyższą 7 lub 5.

Również rozkład temperatur w pozostałych cylindrach jest podobny w poszczególnych punktach pomiarowych.

Zatem można domniemywać, że większe znaczenie w temperaturze poszczególnych głowic cylindrów ma ich umiejscowienie w silniku i złożenie (szczelność układu TPC, szczelność gniazd zaworowych, drożność kanałów oleju) niż rodzaj paliwa.

\section{Podsumowanie}

Analizując uzyskane wyniki, można stwierdzić, że:

1. Możliwe jest zastąpienie w tłokowych silnikach lotniczych paliwa lotniczego 100LL paliwem samochodowym ES95.

2. Zamiana ta nie powoduje istotnej zmiany mocy silnika. Zaobserwowano wzrost mocy jedynie o około $0,5 \%$.

3. Zamiana paliwa powoduje konieczność zmiany jego dawkowania. Zastosowanie benzyny samochodowej zwiększa zużycia paliwa o około $6 \%$. Wynika to $z$ różnicy w gęstości paliw. Zmiana ta powoduje, że

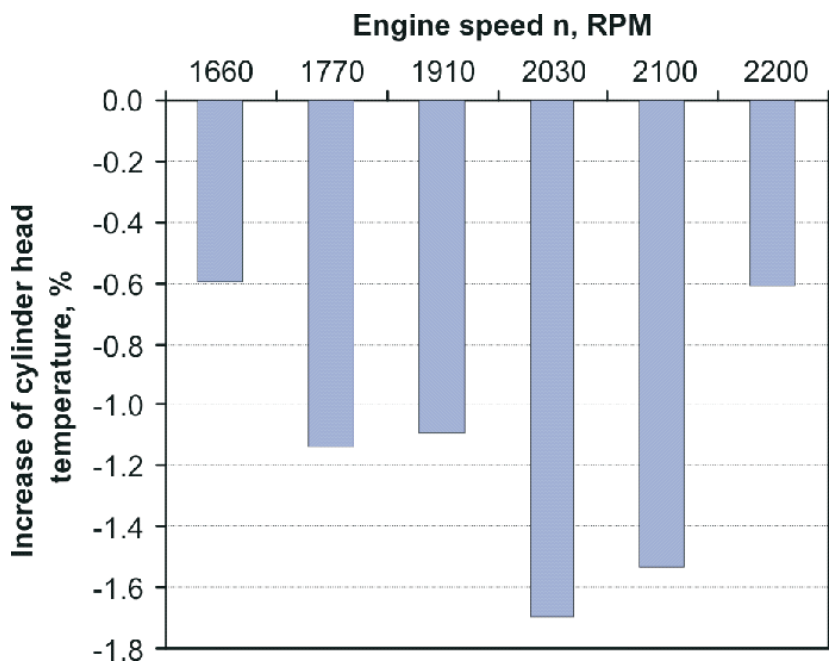

Fig. 8. Cylinder head average temperature change when ES95 substituted 100LL

Rys. 8. Zmiana średniej temperatury głowic po zmianie zasilania silnika z paliwa 100LL na ES95 

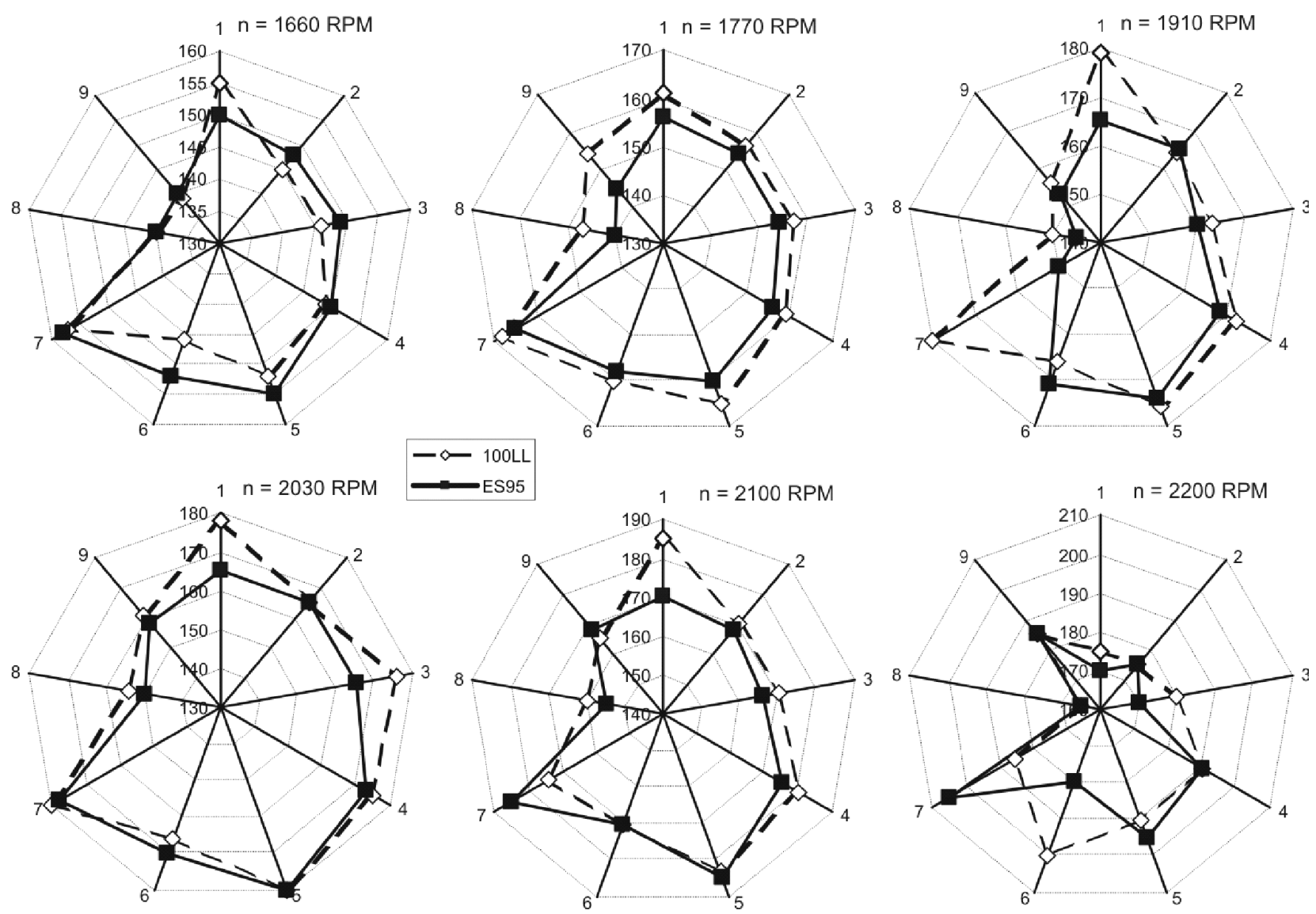

Fig. 9. Distribution of the cylinder head temperatures in the selected operating points depending on a fuel type

Rys. 9. Rozkład temperatury głowic $w$ poszczególnych punktach pracy $w$ zależności od rodzaju paliwa

3. The fuel replacement requires a modification of the fuel dosage. The use of the automotive gasoline results in the increase of fuel consumption by about $6 \%$ because of the difference in the density of the fuels. Such an exchange needs a carburettor to be readjusted or the injection timing to be relevantly extended in the injection system.

4. The exchange of the fuel does not significantly change the head temperatures. The observed decrease by about $1.5 \%$ is miniscule for the differences ranging from 12 to $20 \%$ between the head temperatures of particular cylinders.

5. The fuel type does not influence the temperature distribution in particular cylinders.

It is necessary to emphasise that the tests are only preliminary. It is essential to test particular engine elements in real conditions of operation. Apart from that, it should be tested how the fuel reacts to the fast changes of pressure and temperature that occur when the plane gains altitude, which may lead to a vapour-locks in the low-pressure fuel pipes.

The tests prove that ES95 gasoline can be used to fuel aviation piston engines. The exchange of 100LL gasoline for ES95 gasoline results in a negligible small increase of the engine power observed when the indicated mean effective pressure increases. Simultaneously, the peak pressure slightly increases as well, but as for the indicated mean effective pressure, it is insignificant. The changes of the crank angle of the peak pressure are insignificant as well. niezbędne jest doregulowanie gaźnika lub w przypadku układu wtryskowego - odpowiednie wydłużenie czasów wtrysku.

4. Zmiana paliwa nie powoduje także znaczącej zmiany temperatur głowic. Zauważony spadek o około 1,5\% nie jest istotny przy zróżnicowaniu temperatur głowic pomiędzy poszczególnymi cylindrami rzędu od 12 do $20 \%$.

5. Zmiana paliwa nie wpłynęła na rozkład temperatur cylindrów silnika.

Należy podkreślić, że przeprowadzone badania są jedynie badaniami wstępnymi. Konieczne jest przeprowadzenie dalszych prac, szczególnie nakierowanych na trwałość poszczególnych elementów silnika. Do tych prac dodać należy badania związane $\mathrm{z}$ reakcją paliwa na szybkie zmiany ciśnienia i temperatury występujące podczas wznoszenia samolotu i mogące powodować powstanie korków parowych w niskociśnieniowych przewodach paliwowych układu zasilania. 


\section{Nomenclature/Skróty i oznaczenia}

PRC piston-ring-cylinder/ttok-pierścienie-cylinder
NTP normal temperature and pressure/warunki normlane

RPM revolutions per minute/obroty na minute

\section{Bibliography/Literatura}

[1] Daggett D.L., Hendricks R.C., Walther R., Corporan E.: Alternative fuels for use in commercial aircraft. Boening Company 2007.

[2] Cadet Center for Renewable Energy "Ethanol as an Aviation Fuel”, Technical Brochure, No. 51, US. 97504.

[3] Gonzalez C., Jesik R.L.: ETBE based Aviation Spark-ignition Engine Fuel, Program Report 2003.

[4] Section 7. Development Ground Evaluation of ETBE/N-Butane Fuels, Cessna/FAA ETBE Based Aviation Sparkignition Engine Fuel Program, 2003.

[5] Agrawal H., Sawant A.A., Jansen K., Miller J.W., Cocker D.R.: Characterization of chemical and particulate emissions from aircraft engines, Atmospheric Environment No. $42 / 2008$.

[6] Warunki techniczne. Benzyna lotnicza AVGAS 100LL, WT-99/OBR PR/ND/48, Ośrodek Badawczo- Rozwojowy Przemysłu Rafineryjnego S.A. Płock.
[7] Karta charakterystyki preparatu niebezpiecznego. Benzyna lotnicza 100LL, Ośrodek Badawczo-Rozwojowy Przemysłu Rafineryjnego S.A. Płock, 2000.

[8] AVGAS100LL Data Sweet No. S13001, Schell 2002.

[9] van Basshuysen R., Schäfer F.: Internal Combustion Engine Handbook, Basics, Components, Systems and Perspectives, SAE International, Warrendale 2004.

[10] PKN Orlen SA, Specyfikacja właściwości paliw: Eurosuper 95.

[11] Czarnigowski J., Wendeker M., Jakliński P., Nazarewicz A., Pietrykowski K., Gęca M., Zyska T.: Model of injection system for SI radial aircraft engine, SAE Technical Paper, No 2007-01-1903.

[12] Nazarewicz A., Pietrykowski K., Wendeker M., Czarnigowski J., Jakliński P., Gęca M.: CFD simulation research of the fuel rail of the aircraft radial engine, Silniki Spalinowe, SC2, 2007, P07-C150, pp. 80-93
Mr. Piotr Jakliński, DEng. - doctor in the Department of Thermodynamics, Fluid Mechanics and Aircraft Propulsion, Lublin University of Technology.

Dr inż. Piotr Jakliński - adiunkt $w$ Katedrze Termodynamiki, Mechaniki Plynów i Napędów Lotniczych Politechniki Lubelskiej.

e-mail:p.jaklinski@pollub.pl

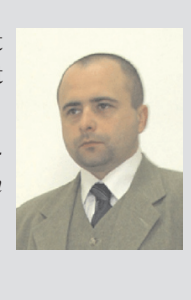

Mr. Jacek Czarnigowski, DEng. - doctor in the Department of Machine Design, Lublin University of Technology.

Dr inż. Jacek Czarnigowski-adiunkt w Katedrze Podstaw Konstrukcji Maszyn Politechniki Lubelskiej. e-mail: j.czarnigowski@pollub.pl
Prof. Mirosław Wendeker, DSc., DEng. - Professor Head of Department of Thermodynamics, Fluid Mechanics and Aircraft Propulsion, Lublin University of Technology.

Prof. dr hab. inż. Mirosław Wendeker - kierownik Katedry Termodynamiki, Mechaniki Ptynów i Napędów Lotniczych Politechniki Lubelskiej.

e-mail:m.wendeker@pollub.pl
Mr. Tomasz Zyska, MSc, DEng. - Laboratory assistant in the Faculty of Electrical Engineering and Computer Science at Lublin University of Technology.

Mgr inż. Tomasz Zyska - pracownik techniczny na Wydziale Elektrotechniki i Informatyki Politechniki Lubelskiej.

e-mail:t.zysk@pollub.pl

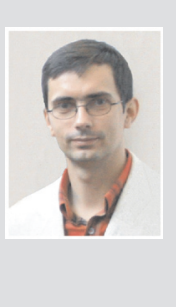

Mr. Mariusz Duk, DEng. - doctor in the Faculty of Electrical Engineering and Computer Science at Lublin University of Technology.

Dr inz. Mariusz Duk-adiunkt na Wydziale Elektrotechniki i Informatyki Politechniki Lubelskiej. e-mail:m.duk@pollub.pl

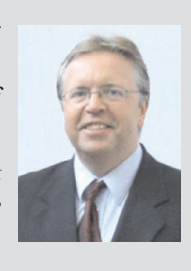

trats

